\title{
Path Coefficient Analysis for Yield and Its Component Traits in Cluster Bean [Cyamopsis tetragonoloba (L.) Taub.] for Vegetable Yield and Seed Yield Traits
}

\author{
Preeti $^{*}$ and V.M. Prasad \\ Department of Horticulture, SHIATS Allahabad-211007, U. P., India \\ *Corresponding author
}

\begin{abstract}
A B S T R A C T
An investigation was carried out to examine the path coefficient analysis of the thirty one genotypes of cluster bean including check, Pusa Navabhar. The investigation was laid out

Keywords

Path analysis,

Cluster bean,

Vegetable pod yield

Article Info

Accepted:

10 March 2018

Available Online:

10 April 2018

in RBD with three replication during kharif- 2015 at the vegetable research farm, Department of Horticulture, SHIATS Allahabad located in South-East part (Zone 4) of Uttar Pradesh. The mean sum of squares due to genotypes was significant for all the seventeen characters. The significant difference among the genotypes for all the characters under study suggested that there was ample scope for selection of promising cluster bean genotypes for vegetable yield and seed yield improvement. Path analysis revealed that high rate of positive direct effects for yield per plant trait were observed at genotypic level by means of the traits number of clusters per plant (0.38), number of pods per cluster $(0.38)$ and ten dry pod weight(1.18). While high rate of positive direct effects for vegetable pod yield per plant trait were observed at genotypic level by means of the traits viz., Plant height at 45 DAS (2.019), Pod length (8.463) and pod breadth (2.711). It indicates that, emphasis can be laid on these characters during selection of genotypes for improvement of seed yield and vegetable pod yield traits.
\end{abstract}

\section{Introduction}

Cluster bean [Cyamopsis tetragonoloba (L.) Taub.] is one of the most important and potential vegetables cum industrial crops grown for its tender pods for vegetable and seed for endospermic gum. Guar seeds are mainly used for extraction of endospermic gum having good binding properties and have high demand in food industry as an ingredient in products like sauces and ice creams etc. In general, guar gum is used as water retainer, soil aggregate and anti-crusting agent in petroleum industry, it is used as gelling and thickening agent. Further, in textile and juice industry, guar gum is used for sizing and as a thickener and stabilizer. Guar gum has also a greater utility in pollution control and acts as an absorbent in waste water treatment, in textile industry as a flocculating and exchanging agent. It is also known as Gawaar in Hindi and Marathi, Goruchikkudu kaya or Gokarakaya in Telugu, Gorikayie in Kannada and Kotthavarai in Tamil reported by (Vahrehvah.com, 2012). Cluster bean is mainly exported to USA, Germany, 
Netherlands, Italy, UK, Japan and France etc worth of about 200 million rupees annually (Singh et al., 2009).

The path coefficient technique developed by Wright (1921) helps in estimating direct and indirect contribution of various components in building up the correlation towards yield. Several path coefficient analysis have been conducted in guar, for vegetable pod yield purpose by Hanchinamani (2003), Girish (2012) and Shabarish and Dharmatti et al., (2014). On the basis of these studies, the quantum importance of individual characters is marked to facilitate the selection programme in cluster bean.

\section{Materials and Methods}

The material comprised of thirty one cluster bean genotypes. These were evaluated at at the vegetable research farm, Department of Horticulture SHIATS, Allahabad located in South-East part (Zone 4) of Uttar Pradesh. The experiment was laid out in a randomized block design with three replications in kharif- 2015. The plot size of single rows each with $3 \mathrm{~m}$ length was followed with spacing of $45 \mathrm{~cm}$ between rows and $20 \mathrm{~cm}$ between the plants. Observations were recorded on five randomly selected plants in each replication of 17 different growth, vegetable yield and seed yield parameters viz., plant height at 45 DAS $(\mathrm{cm})$, plant height at 90 DAS $(\mathrm{cm})$ number of branches per plant, days to fifty per cent flowering, days to first pod picking, pod length $(\mathrm{cm})$, pod breadth $(\mathrm{cm})$, ten fresh pod weight $(\mathrm{g})$, vegetable pods per plant, vegetable pod yield per plant(g), number of clusters per plant, number of pods per cluster, ten dry pod weight $(\mathrm{g})$, ten dry pod seed weight $(\mathrm{g})$, number of seeds in 10 dry pod, 50 seed weight(g), dry pod yield per plant $(\mathrm{g})$.

The path coefficient analysis, a statistical device, which takes into account the cause and effect relation between the variables, is unique in partitioning the association into direct and indirect effect through other independent variables. The path coefficient analysis also measures the comparative significance of causal factors involved. This is simply a standardized partial regression analysis, wherein total correlation value is sub divided into causal scheme and path coefficient was worked out as method suggested by Wright (1921) and Dewey and Lu (1959), respectively. The main objective of this study is to investigate path coefficient for yield and its component traits in cluster bean genotypes for seed yield and vegetable yield parameter.

\section{Results and Discussion}

In the present study the analysis of variance revealed highly significant differences for all 17 characters among the genotypes, indicating a good deal of variation among 31 genotypes of cluster bean. Similar finding is observed in Kumar et al., (2015) Analysis of variance showed that there were significant differences among treatments for concerned characteristics, indicating wide variation among the genotypes. These findings of mean sum of squares are in accordance with the finding of Rai et al., (2012), Mukherjee et al., (2008) and Girish et al., (2012) who also observed significant variability for yield and it's Components in cluster bean. Based on the per se performance for vegetable yield and grain yield per plant, genotypes like, HG-3100, HGS-884, AVT-1 GR-12 and IC-13496 for vegetable yield and HG-04-875, Pusa Navabhar, HGS-881, RGC-1025 and IC-3773 for seed yield showed promising performance for vegetable and seed yield traits respectively.

Cause and effect relationship between yield and yield contributing characters were studied in details through path coefficient analysis. It performed to disclose the causes and effects of 
chain relationships of different yield contributing characters with yield. The results of genotypic path coefficient analysis for seven quantitative characters of vegetable pod yield per plant traits are presented in Table 2 . High rate of positive direct effects were observed at genotypic level by means of the traits viz., Plant height at 45 DAS (2.019), Pod length (8.463) and pod breadth (2.711).

It indicates that, emphasis can be laid on these four characters during selection of genotypes for improvement of yield. Similar findings were also reported by Sheela et al., (2014) for the character pod length, Vidya and Sunny (2002) in yard-long bean and Rakesh et al., (2011) in cluster bean. While plant height at 90 DAS (-0.914), number of branches per plant (-0.663), days to fifty percent flowering
(-4.690), ten fresh pod weight (-7.610) and vegetable pods per plant (-2.672) at genotypic level had negative direct effect on vegetable pod yield per plant, indicating this trait is not the criteria for yield improvement

Pod breadth showed negative indirect effect with plant height at 45 DAS (1.522), number of branches per plant $(-0.66)$ and vegetable pods per plant (-1.338), while ten fresh pod weight showed high negative indirect effect with plant height at 90 DAS (-4.132), days to fifty per cent flowering (-3.648), days to first pod picking (-1.052), pod length (-7.091) and pod breadth (-4.898) as well as character ten fresh pod weight showed high negative direct effect with vegetable pod yield per plant. Which indicates selection on the basis of these characters are not beneficial (Table 1).

Table.1 Analysis of variance for different growth vegetable and seed yield traits in cluster bean

\begin{tabular}{|c|c|c|c|c|}
\hline S. No & Source of variation/characters & Replication & Treatment & Error \\
\hline A. & \multicolumn{4}{|l|}{ Growth parameter } \\
\hline $\begin{array}{l}1 . \\
2 . \\
3 .\end{array}$ & $\begin{array}{l}\text { Plant height at } 45 \text { DAS }(\mathrm{cm}) \\
\text { Plant height at } 90 \text { DAS }(\mathrm{cm}) \\
\text { Number of branches per plant }\end{array}$ & $\begin{array}{c}166.08 \\
465.50 \\
7.70\end{array}$ & $\begin{array}{l}114.43 * * \\
705.97 * * \\
66.99 * *\end{array}$ & $\begin{array}{c}6.05 \\
48.55 \\
1.05\end{array}$ \\
\hline B. & \multicolumn{4}{|l|}{ Vegetable pod yield parameter } \\
\hline $\begin{array}{l}1 . \\
2 . \\
3 . \\
4 . \\
5 . \\
6 . \\
7 .\end{array}$ & $\begin{array}{l}\text { Days to fifty per cent flowering } \\
\text { Days to first pod picking } \\
\text { Pod length }(\mathrm{cm}) \\
\text { Pod breadth }(\mathrm{cm}) \\
\text { Ten fresh pod weight }(\mathrm{g}) \\
\text { Vegetable pods per plant } \\
\text { Vegetable pod yield per plant }(\mathrm{g})\end{array}$ & $\begin{array}{c}17.43 \\
43.19 \\
0.47 \\
0.004 \\
47.21 \\
1504.13 \\
1879.8\end{array}$ & $\begin{array}{c}5.80 * * \\
15.69 * * \\
11.71 * * \\
0.026 * * \\
153.21 * * \\
10629.30 * * \\
4950.17 * *\end{array}$ & $\begin{array}{c}2.83 \\
4.37 \\
0.18 \\
0.01 \\
3.90 \\
544.48 \\
330.03\end{array}$ \\
\hline C. & \multicolumn{4}{|l|}{ Seed yield parameters } \\
\hline $\begin{array}{l}1 . \\
2 . \\
3 . \\
4 . \\
5 . \\
6 . \\
7 .\end{array}$ & $\begin{array}{l}\text { Number of clusters per plant } \\
\text { Number of pods per cluster } \\
\text { Ten dry pod weight }(\mathrm{g}) \\
\text { Ten dry pod seed weight }(\mathrm{g}) \\
\text { Number of seeds in } 10 \text { dry pod } \\
50 \text { seed weight }(\mathrm{g}) \\
\text { Dry pod yield per plant }(\mathrm{g})\end{array}$ & $\begin{array}{c}3.43 \\
0.09 \\
0.67 \\
0.01 \\
15.63 \\
0.01 \\
0.32\end{array}$ & $\begin{array}{c}402.38 * * \\
3.29 * * \\
2.59 * * \\
0.56 * * \\
142.19 * * \\
0.24 * * \\
1868.44 * *\end{array}$ & $\begin{array}{c}11.70 \\
0.69 \\
0.22 \\
0.06 \\
11.24 \\
0.05 \\
0.66\end{array}$ \\
\hline
\end{tabular}

All significant at $1 \%$ level 
Table.2 Path coefficient analysis for vegetable yield and its component characters in cluster bean

\begin{tabular}{|c|c|c|c|c|c|c|c|c|c|}
\hline @ & $\begin{array}{c}\text { Plant } \\
\text { height at } \\
\text { 45 DAS } \\
(\mathrm{cm})\end{array}$ & $\begin{array}{c}\text { Plant } \\
\text { height at } \\
90 \text { DAS } \\
(\mathrm{cm})\end{array}$ & $\begin{array}{c}\text { Number } \\
\text { of } \\
\text { branches } \\
\text { per plant }\end{array}$ & $\begin{array}{c}\text { Days to } \\
50 \% \\
\text { flowering }\end{array}$ & $\begin{array}{l}\text { Days to } \\
\text { first pod } \\
\text { picking }\end{array}$ & $\begin{array}{l}\text { Pod } \\
\text { length } \\
(\mathrm{cm})\end{array}$ & $\begin{array}{c}\text { Pod } \\
\text { breadth } \\
\text { (cm) }\end{array}$ & $\begin{array}{c}\text { Ten fresh } \\
\text { pod } \\
\text { weight (g) }\end{array}$ & $\begin{array}{l}\text { Vegetable } \\
\text { pods/plant }\end{array}$ \\
\hline Plant height at 45 DAS (cm) & 2.019 & -0.266 & 0.633 & -1.088 & -0.517 & -1.394 & -1.133 & -1.304 & 1.421 \\
\hline Plant height at 90 DAS (cm) & 0.120 & -0.914 & -0.082 & -0.364 & -0.180 & -0.530 & -0.386 & -0.496 & 0.336 \\
\hline Number of branches per plant. & -0.208 & -0.060 & -0.663 & 0.056 & 0.350 & 0.000 & 0.161 & 0.106 & -0.185 \\
\hline Days to $50 \%$ flowering & 2.528 & -1.866 & 0.393 & -4.690 & -1.579 & -3.170 & -3.349 & -2.248 & 3.355 \\
\hline Days to first pod picking & -0.034 & 0.026 & -0.069 & 0.044 & 0.131 & 0.021 & 0.067 & 0.018 & -0.011 \\
\hline Pod length $(\mathrm{cm})$ & -5.843 & 4.907 & 0.005 & 5.720 & 1.377 & 8.463 & 5.652 & 7.885 & -5.973 \\
\hline Pod breadth $(\mathrm{cm})$ & -1.522 & 1.146 & -0.660 & 1.936 & 1.385 & 1.811 & 2.711 & 1.745 & -1.338 \\
\hline Ten fresh pod weight (g) & 4.915 & -4.132 & 1.213 & -3.648 & -1.052 & -7.091 & -4.898 & -7.610 & 5.590 \\
\hline Vegetable pods/plant & -1.881 & 0.982 & -0.744 & 1.912 & 0.226 & 1.886 & 1.318 & 1.963 & -2.672 \\
\hline rG & 0.095 & -0.175 & 0.026 & -0.122 & 0.141 & -0.004 & 0.143 & 0.059 & 0.523 \\
\hline
\end{tabular}

Residual $=1.2514$

*Significant at $5 \% * *$ Significant at $1 \%$

rG. Genotypic correlation with vegetable pod yield per plant

Table.3 Path coefficient analysis for seed yield and its component characters in cluster bean

\begin{tabular}{|c|c|c|c|c|c|c|}
\hline @ & $\begin{array}{l}\text { Number of } \\
\text { clusters/plant }\end{array}$ & $\begin{array}{l}\text { Number of } \\
\text { pods/cluster }\end{array}$ & $\begin{array}{l}\text { Ten dry pod weight } \\
\text { (g) }\end{array}$ & $\begin{array}{c}\text { Ten dry pod } \\
\text { seed weight }(\mathrm{g})\end{array}$ & $\begin{array}{l}\text { Number of } \\
\text { seeds/10 dry } \\
\text { pod }\end{array}$ & $\begin{array}{l}50 \text { seed } \\
\text { weight } \\
(\mathrm{g})\end{array}$ \\
\hline Number of clusters/plant & 0.38 & 0.16 & -0.04 & -0.09 & 0.01 & -0.02 \\
\hline Number of pods/cluster & 0.16 & 0.38 & -0.11 & -0.06 & -0.01 & -0.19 \\
\hline Ten dry pod weight (g) & -0.12 & -0.36 & 1.18 & 1.03 & 0.55 & 0.85 \\
\hline Ten dry pod seed weight (g) & 0.05 & 0.03 & -0.19 & -0.21 & -0.11 & -0.10 \\
\hline Number of seeds/10 dry pod & -0.01 & 0.01 & -0.11 & -0.12 & -0.23 & -0.09 \\
\hline 50 seed weight $(\mathrm{g})$ & 0.02 & 0.27 & -0.39 & -0.25 & 0.20 & -0.54 \\
\hline rG & 0.48 & 0.49 & 0.34 & 0.29 & 0.38 & -0.09 \\
\hline
\end{tabular}


Ten fresh pod weight showed high positive indirect effect with plant height at 45 DAS (4.915), number of branches per plant (1.213) and vegetable pods per plant (5.59), while the character plant height at 90 DAS (4.907), number of branches per plant (0.005), days to $50 \%$ flowering (5.720), days to first pod picking (1.377), pod breadth (5.652) and ten fresh pod weight (7.885) showed positive indirect effect with pod length. It indicates that, emphasis can be laid on these four characters during selection of genotypes for vegetable pod yield improvement.

The results of genotypic path coefficient analysis for seven quantitative characters of seed yield parameter presented in Table 3 . High rate of positive direct effects were observed at genotypic level by means of the traits viz., number of clusters per plant (0.38), number of pods per cluster (0.38) and ten dry pod weight (1.18). It indicates that, emphasis can be laid on these three characters during selection of genotypes for improvement of seed yield. While ten dry pod seed weight ($0.21)$, number of seeds per ten dry pod $(-0.23)$ and fifty seed weight at genotypic level had negative direct effect on seed yield per plant, indicating this trait is not the criteria for yield improvement. Number of clusters per plant showed positive indirect effect with number of pods per cluster and number of seeds per ten dry pod (0.01). While ten dry pod weight showed high positive indirect effect with ten dry pod seed weight, number of seeds per pod (0.55) and fifty seed weight (0.85) and Fifty seed weight showed positive indirect effect with number of clusters per plant (0.02), number of pods per cluster (0.27) and number of seeds per pod (0.20). It indicates selection on the basis of these characters is rewarding for the improvement of seed yield per plant.

In conclusion, from the present study it can be concluded that in selection programme, the prime importance should be given to plant height at 45 DAS (cm), Pod length $(\mathrm{cm})$ and pod breadth $(\mathrm{cm})$, number of clusters per plant, number of pods per cluster and ten dry pod weight ( $\mathrm{g}$ ) for vegetable pod yield and seed yield improvement in cluster bean, since these characters recorded significant high direct effect on pod yield and seed yield traits respectively.

\section{References}

Dewey, D.H. and Lu, K.H. 1959. A correlation and path analysis of components of crested wheat grass production. Agron. J., 51(9): 515-518.

Girish, M.H., Gasti, V.D., Mastiholi, A.B., Thammaiah, N., Shantappa, T., Mulge, R. and Kerutagi, M.G. 2012. Correlation and path analysis for growth, pod yield, seed yield and quality characters in cluster bean [Cyamopsis tetragonoloba (L.) Taub.]. Karnataka J. Agric. Sci., 25(4): 498502.

Hanchinamani, N.G. 2003. Studies on genetic variability and genetic divergence in cluster bean [Cyamopsis tetragonoloba (L.) Taub.]. M.Sc. (Hort.) Thesis, University of Agricultural Sciences, Dharwad, Karantaka (India).

Kumar, D. and Singh, N.B. 2002. Guar in India. Scientific Publishers (India), Jodhpur.

Kumar, V., Ram, R. B., Rajvanshi, S. K. and Dohre, S. 2015. Study on genetic variability, heritability and genetic advance for yield and yield attributing characters in Cluster bean [Cyamopsis tetragonoloba (L). Taub.]. International Journal of Agricultural Science and Research 5(4): 235-246.

Mukherjee, Subhra, Gupta, Suparna and Bhowmik, N. 2008. Genetic Variability of important quantitative characters in modern wheat (Triticum aestivum L.) cultivars in Tarai Region of West 
Bengal. Environment and Ecology, 26(2): 683-686.

Rai P. S., Dharmatti P. R., Shashidhar T. R., Patil R. V. and Patil P. R. 2012. Genetic variability studies in clusterbean (Cyamopsis tetragonoloba (L.) Taub). Karnataka J. Agric. Sci. 25: 108-111.

Rakesh, P., Manjit, S. and Henry, A. 2011. Stability, correlation and path analysis for seed yield and yield-attributing traits in clusterbean (Cyamopsis tetragonoloba). Indian J. Agric. Sci., 81 (4): 309-313.

Shabarish, P. R. and Dharmatti, P. R. 2014. Correlation and path analysis for cluster bean vegetable pod yield. The bioscan. 9(2): 811-814.
Sheela N. Malaghan, Madalageri. M. B. and Kotikal Y. K. 2014. Correlation and Path Analysis in Cluster bean [Cyamopsis Tetragonoloba (L.) Taub.] for vegetable pod yield and its component characters. The bioscan. 9(4): 1609-1612, 2014

Singh, U.P., Tripati, S.N. and Natarajan, S. 2009. Guar, Crop profile, pp.178.

Vahrehvah.com. 2012. Redefining Indian food article. Cluster bean.

Vidya, C. and Sunny, K. O. 2002. Correlation and path analysis in yard-long bean. $J$. of Tropical Agric. 40: 48-50.

Wright, S. 1921. Correlation and causation. $J$. Agric. Res., 20: 557-587.

\section{How to cite this article:}

Preeti and Prasad, V.M. 2018. Path Coefficient Analysis for Yield and Its Component Traits in Cluster Bean [Cyamopsis tetragonoloba (L.) Taub.] for Vegetable Yield and Seed Yield Traits. Int.J.Curr.Microbiol.App.Sci. 7(04): 974-979. doi: https://doi.org/10.20546/ijcmas.2018.704.104 